\title{
AKSESIBILITAS BAGI ANAK BERKEBUTUHAN KHUSUS DALAM LINGKUP PENDIDIKAN SEKOLAH INKLUSI DI KARISIDENAN SURAKARTA
}

\author{
${ }^{1}$ Abwatie Al Khakim, ${ }^{2}$ Donni Prakosha, ${ }^{3}$ Dwi A Himawanto \\ ${ }^{1,2,3}$ Magister Pendidikan Luar Biasa, Universitas Sebelas Maret, Surakarta, Indonesia
}

\begin{abstract}
Abstrak: This research aims to identify condition of inclusive school in Solo especially for handicapped children. This is a qualitative research. Focuses of this research are first, the accessibility of inclusive school and second, identifying ideal inclusive school for handicapped children. it is located in two schools namely at $\mathrm{Al}$ Firdaus High School of Sukoharjo and Brumantakan Elementary School Solo. Method to collect data is observation, interview, and documentation. Conclusion drawn from this research is accessibility of inclusive school for handicapped children is not fulfilled completely. There is still barrier in completing condition of good and proper accessibility in inclusive school.
\end{abstract}

Keywords: accessibility, handicapped children, inclusive school

\section{Latar Belakang}

Permasalahan dalam hal aksesibilitas sebenarnya sudah lama menjadi perbincangan. Aksesibilitas sebenarnya bukan hanya milik orangorang normal saja tetapi juga untuk orang berkebutuhan khusus. Pemerintah mengeluarkan beberapa peraturan atau kebijakan untuk penyediaan fasilitas bagi orang-orang berkebutuhan khusus yaitu Undang-Undang No.4 Tahun 1997 Tentang Penyandang Cacat yang kemudian ditindaklanjuti dengan beberapa keputusan menteri yang menyangkut tentang akses fasilitas bangunan fisik yaitu Keputusan Menteri Pekerjaan Umum No. 468 Tahun 1998 tentang Aksesibilitas yang berisi Petunjuk teknis untuk bangunan dan lingkungan yang aksesibel bagi para penyandang ketunaan.

* Corresponding author: Abwatie Al Khakim abwatieal@gmail.com

Published online at http://IJDS.ub.ac.id

Copyright @ 2017PSLD UB Publishing. All Rights Reserved
Selanjutnya Keputusan Menteri Transportasi No. KM 71 tahun 1999 tentang Aksesibilitas bagi Penyandang cacatp ada fasilitas transportasi umum, petunjuk aksesibilitas fasilitas transportasi darat, laut, dan udara bagi penyandang cacat.

Aksesibilitas dalam hal pendidikan, khususnya dalam pendidikan inklusi bagi anak berkebutuhan khusus sampai saat ini dirasa masih kurang. Baik dalam hal kenyamanan dan keamanan. Hal tersebut dikarenakan masih banyak sekolah inklusi yang belum menyediakan sarana aksesibilitas yang memadai dan memudahkan anak berkebutuhan khusus untuk mendapatkan persamaan kesempatan untuk lebih mempermudahkan mereka dalam segala kegiatan pembelajaran di sekolahnya.

Wujud aksesibilitas bagi anak berkebutuhan khusus di sekolah inklusi dapat berupa running text yang dipampang di sekolah untuk memudahkan siswa tuna 
rungu untuk mengetahui informasi yang ada. Bagi siswa autis dapat menghindari adanya sudut lancip pada setiap bangunan, bagi siswa tuna daksa wujud aksesibilitas dapat berupa diperbanyaknya bidang miring dan lantai tidak licin yang ada di sekolah sehingga memudahkan kursi roda untuk berjalan di atasnya. Secara formal akses pendidikan inklusi sudah dijamin oleh Undang-Undang Dasar Nomor 20 Tahun 2003 tentang Sistem Pendidikan Nasional dan Peraturan Menteri Pendidikan Nasional Nomor 70 Tahun 2009 tentang Pendidikan Inklusi. Kebijakan ini memungkinkan penyandang disabilitas untuk mengakses pendidikan bersama dengan siswa umum, sesuai dengan kemampuan penyandang disabilitas.

\section{Metode Penelitian}

Pada penelitian ini, peneliti menggunakan metode penelitian kualitatif deskriptif. Tujuan dari metode penelitian ini untuk menggambarkan bagaimana keadaan akasesibilitas di sekolah inklusi bagi anak berkebutuhan khusus.

Penelitihanya mengembangkan konsep dan menghimpun fakta tetapi tidak melakukan pengujian hipotesis. Ada pendapat dari Gorman \& Clayton bahwa metode penelitian ini adalah untuk melaporkan meaning of event dari apa yang diamati oleh peneliti (Santana, 2007: 28). Pada tahap laporannya, berisi amatan berbagai kejadian dan interaksi yang diamati langsung oleh peneliti dari tempat kejadian (Santana, 2007: 28).

Penelitian diskriptif mempelajari masalah-masalah dalam masyarakat, serta tata cara yang berlaku dalam masyarakat serta situasi-situasi tertentu, termasuk tentang hubungan, kegiatan-kegiatan, sikap-sikap, pandangan-pandangan, serta proses-proses yang sedang berlangsung dan pengaruhpengaruh dari suatu fenomena (Nazir, 2005: $55)$.

\section{Hasil Penelitian}

Hasil analisis data tentang aksesibiltas bagi anak berkebutuhan khusus di sekolah inklusi di karisidenan Surakarta yaitu:

a. KomponenAksesibilitas

Didalam komponen aksesibilitas terterdapat point-point yang mengukur sejauh mana upaya sekolah dalam menyediakan kemudahan-kemudahan dalam penyelenggaraan pendidikan bagi anak berkebutuhan khusus dari masalah bangunan dan tata ruang sekolah yang disesuaikan dengan anak berkebutuhan khusus contohnya anak tuna daksa di sekolah inklusi Sekolah Menengah Al Firdaus masih terganggu dalam melakukan mobilitas karena aksesibiltasnya tidak sesuai dengan Peraturan Mernteri PU tahun 2007 yakni: Ramp (bidang miring pengganti tangga bagi anak tuna daksa) dengan perbandingan 1:12 sampai dengan 1:15 antara tinggi dan alas ramp agar memudahkan mendorong kursi roda, lebar pintu dibuat selebar kursi roda, toilet duduk dengan railing (tempat berpegangan).

b. KomponenSaranadanPrasarana

Di dalam komponen ini terdapat data yang menyangkut sejauh mana aliran dana dan bantuan dari pemerintah maupun yayasan untuk menyelenggarakan pendidikan inklusi di sekolah tersebut. Beberapa guru di sekolah tersebut telah menggunakan media sebagai sarana pembelajaran. Hal ini sejalan dengan Rahardja (2008) yang menyatakan bahwa semua guru sepakat bahwa media itu perlu dalam pembelajaran. Dalam memilih media, perlu disesuaikan dengan kebutuhan, situasi dan kondisi masing-masing siswa.

c. Komponen Model Pembelajaran

Di dalam komponen model pembelajaran mencakup tentang kurikulum yang digunakan dalam mengajar siswa $\mathrm{ABK}$, frekuensi pemberian Program Pembelajaran Individual (PPI) bagi siswa hingga hasil belajar siswa ABK di sekolah tersebut. Di ketahui di SM Al Firdaus dan SDN Brumantakan telah membuat Program Pembelajaran Individual bagi siswa berkebutuhan khusus serta Program Pendukung untuk 1 semester. 


\section{Kesimpulan}

Setelah peneliti mengobservasi sekolah inklusi di Sekolah Menengah Al Firdaus dan SDN Brumantakan belum memenuhi standar aksesibiltasi untuk anak berkebutuhan khusus di sekolah tersebut. Adanya faktor kurangnya pengetahuan maupun dana untuk membuat sarana aksesibiltas yang baik untuk anak berkebutuhan khusus di sekolah tersebut. Sehingga berpengaruh terhadap proses pembelajaran dan mobilitas anak berkebutuhan khusus tersebut di sekolah inklusi.

\section{Daftar Pustaka}

Nazir, M. (2005). Metode Penelitian. Bogor: Ghalia Indonesia.

Peraturan Menteri Pendidikan Nasional Nomor 70. (2009). Pendidikan Inklusif bagi Peserta Didik yang Memiliki
Kelainan dan Memiliki Potensi Kecerdasan dan latau Bakat Istimewa.http://peduliinklusi.blogspot.com 12009/11/permendiknas-no-70-tahun-2009 tentang.html, diakses pada tanggal 12 Oktober 2016.

Undang-Undang Nomor 20. (2003). UU Sistem Pendidikan Nasional No. 20 Tahun 2003.http://www.inherentdikti.net/files/sis diknas.pdf, diakses padatanggal12 Oktober 2016.

Rahardja, D. (2008). Pendidikan Luar Biasa Dulu dan Sekarang .http://djrahardjablogspot.com/2008/09/pen didikan-luar-biasa-dulu-dan-sekarang.html , diakses pada tanggal 12 Oktober 2016

Santana, S. (2007). Menulis Ilmiah Metode Penelitian Kualitatif. Jakarta: Yayasan Obor Indonesia 